\title{
Effect of Methyl Parathion on Survival and Development of Tadpoles of Indian Cricket frog Fejervarya limnocharis
}

\author{
Hunasanahalli Puttaswamygowda Gurushankara ${ }^{1}$, Sannanegunda Venkatarama Bhatta Krishnamurthy ${ }^{2 *}$, Venkateshaiah Vasudev ${ }^{3}$ \\ ${ }^{1}$ Department of Animal Science, School of Biological Sciences, Central University of Kerala, Riverside Transit Campus, Padanakkad, \\ Kerala, India. \\ ${ }^{2}$ Department of Environmental Science, Kuvempu University, Jnana Sahyadri, Shankaraghatta, India. \\ ${ }^{3}$ Department of Studies in Bioscience, University of Mysore, P.G. Center, Karnataka, India
}

\begin{abstract}
Amphibian populations are declining due to various causes including pesticide contamination in natural habitat. We evaluated the effect of Methyl Parathion (MPT) an organophosphate pesticide on survival and development of common paddy field frog Fejervarya limnocharis in a laboratory condition. Effect of $0 \mu \mathrm{g}$ MPT/L, $500 \mu \mathrm{g}$ MPT/L, $1000 \mu \mathrm{g} \mathrm{MPT/L,} 1500 \mu \mathrm{g}$ MPT/L, $2000 \mu \mathrm{g} \mathrm{MPT} / \mathrm{L}$ and $3000 \mu \mathrm{g}$ MPT/L was studied using static toxicity test for a duration of 28 days. MPT reduced the survival of tadpole. The mortality was increased with the increased concentration of pesticide. The development decreased with increased MPT concentrations. At higher concentrations, MPT induced slow development and tadpoles failed to metamorphose. It is assumed that slow development could affect the early larval life and amphibian population in the agroecosystem.
\end{abstract}

Keywords: Cricket frog, Growth, Methyl parathion, Survival, Tadpoles

\section{INTRODUCTION}

Amphibian population decline has been reported worldwide since the late 1960s. Several factors including pesticide contamination are considered to contribute the decline of amphibian populations [1-4]. Many amphibian species are known to dwell in agroecosystem [5-6]. Agriculture activities and management practices have induced several consequences in amphibian habitat and their habitats suffer from nitrogen pollution, agrochemical contamination and heavy metals [710]. Most important agrochemicals inducing the problem on amphibians are pesticides and synthetic fertilizers. Pesticides can affect many amphibians due to acute lethal and sublethal toxicities. The effects of pesticides at sublethal levels include behavioral changes, endocrine disruptions, decreased growth and development, increased developmental abnormality, susceptibility to diseases [11-15]. Many studies have showed that the pesticides might be a major cause of global amphibian population decline [16-19]. Interest in con-

\footnotetext{
*Corresponding author:

Sannanegunda Venkatarama Bhatta Krishnamurthy Department of Environmental Science, Kuvempu University, Jnana Sahyadri, Shankaraghatta 577451, Karnataka, India E-mail: svkrishnamurthy@gmail.com
}

sidering the effects of pesticides on amphibians emerged from the fact that the pesticides are also an important factor for global amphibian declines [8] this could have a negative impact on natural ecosystems [20].

In the Western Ghats, many amphibians are living and breeding in shallow water bodies within the vicinity of rice paddy fields. Their breeding period coincides with the application of agrochemicals, including pesticides and fertilizers [21-23]. Studies conducted by Gurushankara et al. [24] and Hegde and Krishnamurthy [10] have recorded high incidence of abnormal frogs in agrochemical contaminated habitats in the Western Ghats. Compared to native habitats, Patel et al. [25] recorded a maximum morphological abnormalities $(>10.8 \%)$ in Fejervarya limnocharis (Indian Cricket Frog) living in highly contaminated agroecosystem of Rice paddy fields. This frogs spend most of their time in shallow aquatic habitats of rice paddy fields and concomitant water bodies and breeds during the monsoon season [22, 26] and use shallow waters of Rice paddy fields for breeding and development of tadpoles. However, the time of reproduction and larval development coincide with agrochemical applications in rice paddy field. Among the agrochemicals, organophosphate 
pesticides (OPs), a class of acetylcholinesterase in hibitors, are intensively used in agriculture to reduce insect pest population. Among the OPs, Malathion and Methylparathion (MPT) are intensively used as a potent insecticide in rice cultivation. These two insecticides together constitute $65 \%$ of total pesticides usage [21]. In general, the biological actions of OPs are due primarily to the inhibition of acetylcholinesterase (AChE), which causes a toxic and potentially lethal buildup of the neurotransmitter acetylcholine (ACh). MPT was reported to affect the reproductive system in fish, amphibians, birds, and mammals[27]. However, the effect of MPT is found to vary among different species [28], bioaccumulate and produce the negative impact on the reproductive system of frogs [29]. Since MPT is widely used along with other OPs in rice paddy fields, it is of interest to determine the effect of MPT on survival and development of common rice paddy field frog F. limnocharis.

\section{MATERIALS AND METHODS \\ Experimental Design}

More than 800 pre-feeding tadpoles of F. limnocharis from different egg clutches were collected from natural pristine habitats (Loc; $13^{\circ} 18^{\wedge}-75^{\circ} 25^{\prime}$ and $13^{\circ}-22^{\prime}-75^{\circ} 28^{\prime}$; altitude range: $720-1060 \mathrm{~m}$ MSL), remotely located away from human activities and crop lands. Tadpoles were collected in the month of July and were transported to the laboratory and maintained in reconstituted water in a large container (100 L) until tadpoles reach Gosner stage 25 [30]. Reconstituted water was formulated by dissolving $96 \mathrm{mg}$ $\mathrm{NaHCO}_{3}, 60 \mathrm{mg} \mathrm{CaSO}_{4} \cdot 2 \mathrm{H}_{2} \mathrm{O}, 60 \mathrm{mg} \mathrm{MgSO}_{4} \cdot 7 \mathrm{H}_{2} \mathrm{O}$ and $4 \mathrm{mg} \mathrm{KCl}$ with a liter of deionized water. This reconstituted water was used throughout the experiment. Tadpoles were maintained on a 14:10 hour light: dark cycle at a room temperature of $22-25{ }^{\circ} \mathrm{C}$ throughout the experiment. Tadpoles were fed boiled spinach, provided ad libitum following methods of Sabnis and Kuthe [31].

We used Methyl parathion (O, O-dimethyl O-4nitrophenyl phosphorothioate) 50\% EC (Registration No. 5-11(34) methyl parathion (EC)-2, Batch No. CC4111, Bayer AG Germany), obtained from the local market as a test chemical. We followed a factorial design to test the toxicity of MPT on tadpoles. This comprises 0 (control), Acetone control, 500, 1000, 1500, 2000 and $3000 \mu \mathrm{g} \mathrm{MPT} / \mathrm{L}$ as test concentrations. We consider these concentrations as environmentally realistic as field concentration of MPT immediately after application found to vary between 1000 to 3500 $\mu \mathrm{g} / \mathrm{L}$ in different rice paddy fields of the area. Analytical grade Acetone (purity 99\%, Product No 33515, Batch No NL 27616403 v, Qualigens Fine Chemicals) was used to dissolve and make the stock solution of MPT. The LC50 of methyl parathion for tadpoles at 24, 48, 72 and 96 hours were found to be $11.06,8.86,7.52$ and $6.50 \mathrm{mg} / \mathrm{L}$ respectively [32].

Since we have collected pre-feeding tadpoles hatched out from different egg masses, a random selection of twenty tadpoles (Gosner stage 25) were picked up to expose to each test solution. Each tadpole of all test groups is exposed to test solution in a separate inert polyethylene circular container (Diameter: $20 \mathrm{~cm}$, Depth: $8 \mathrm{~cm}$, Volume: $1500 \mathrm{~mL}$ ) containing 1 liter of test solution. As a result, each group comprises $20 \mathrm{ex}-$ perimental containers with one tadpole in it. (i.e total 7 test concentrations $\times 20$ tadpoles in 140 containers). At an interval of 7 days, until the $28^{\text {th }}$ day, the length, body mass and changes in Gosner stage were recorded. The length of the tadpole was measured using an electronic calipers and body mass was recorded with the help of electronic balance (Model: Anamed: M-300, precision $0.001 \mathrm{~g}$ ). The total length and body mass (BM) of tadpoles at the beginning of the experiment were found to be $20.0 \pm 0.65 \mathrm{~mm}$ and $0.11 \pm 0.012 \mathrm{~g}$ respectively. The total number of tadpoles surviving at the end of 28 days was recorded and average days up to which tadpoles survive under a selective exposure of MPT was considered as mean survival time in days. To maintain constant test concentration and to reduce the load of excretory material and decaying food in the test media, the test solution was changed once in two days with the same concentration of MPT. The dosing solutions were formulated immediately before changing the solution in the tadpole containers. Tadpole were fed with boiled spinach ad libitum $(\approx 100$ $\mathrm{mg} /$ tadpole/day).

For all the statistical analysis, the response given out by each tadpole from a group is pooled. Since the differences in data recorded for control and acetone control are insignificant $(\rho>0.50)$, we did not consider data registered for acetone treated tadpoles to any statistical calculations. We used ANOVA to check the significance of differences in survival, the increment in length, and the body mass of tadpoles between controls and treatment groups. The correlation between test concentration and response was estimated using Karl Pearson Correlation. SPSS ver. 20 was used for all statistical analysis. 


\section{RESULTS AND DISCUSSION}

\section{Tadpole Survival}

Tadpole survival was $99.84 \%$ in control followed by $60 \%, 35 \%, 25 \%, 20 \%$ and $10 \%$ recorded in $500 \mu \mathrm{g}$ MPT/L, $1000 \mu \mathrm{g}$ MPT/L, $1500 \mu \mathrm{g}$ MPT/L, $2000 \mu \mathrm{g}$ $\mathrm{MPT} / \mathrm{L}$ and $3000 \mu \mathrm{g} \mathrm{MPT} / \mathrm{L}$ respectively for a period of 28 days. For the exposure of $3000 \mu \mathrm{g}$ MPT/L, tadpoles survived only up to 7 days. Figure 1 presents the survival time (days) of tadpole against MPT concentrations used in the experiment. Similar to tadpole survival (\%), survival time in different treatment groups have decreased constantly with the increase in concentration of MPT $(r=-0.94, \rho=0.006)$. Survival time recorded for different treatment groups showed significant differences $(\mathrm{F} 5,14=207.54, \mathrm{p}=0.0001)$.

\section{Length and Body Mass of Tadpoles}

In control group, the length of the tadpoles over the time have followed the typical curvature of normal development of anuran tadpoles (Figure 2); after a continuous increase and once tadpole have reached a threshold level (around 21 ${ }^{\text {st }}$ day; stage 42 ) the length did not show increase. Tadpoles developed limb buds and reduction in tail length has occurred. A similar trend was also recorded in tadpoles treated with $500 \mu \mathrm{g}$ MPT/L. However, froglet did not emerge at the end. The length of the tadpoles recorded at the end of the experiment for control and $500 \mu \mathrm{g} \mathrm{MPT} / \mathrm{L} \operatorname{did}$ not show any significant differences $(\mathrm{F} 1,5=2.18, \mathrm{p}=$ 0.206). In $1000 \mu \mathrm{g} \mathrm{MPT} / \mathrm{L}, 1500 \mu \mathrm{g} \mathrm{MPT} / \mathrm{L}$ and 2000 $\mu \mathrm{g} \mathrm{MPT} / \mathrm{L}$ exposure, surviving tadpole showed a continuous increase in their length and did not follow observed pattern for control and $500 \mu \mathrm{g} \mathrm{MPT} / \mathrm{L}$ exposures. There is a significant differences in length recorded for control and $1000 \mu \mathrm{g} \mathrm{MPT/L}(\mathrm{F} 1,5=9.1$, $\mathrm{p}=0.015), 1500 \mu \mathrm{g}$ MPT/L (F1, $5=12.41, \mathrm{p}=0.0075)$, and $2000 \mu \mathrm{g} \mathrm{MPT} / \mathrm{L}(\mathrm{F} 1,5=14.78, \mathrm{p}=0.005)$, while in $3000 \mu \mathrm{g}$ MPT/L, all tadpoles were dead in 7 days.

Body Mass has followed the similar trend as exhibited for length (Figure 3). In control and $500 \mu \mathrm{g}$ $\mathrm{MPT} / \mathrm{L}$ exposure, tadpoles exhibited the normal growth pattern and did not exhibit considerable difference to that of control (F1, $5=3.27, \mathrm{p}=0.109)$. In $1000 \mu \mathrm{g}$ MPT/L, $1500 \mu \mathrm{g}$ MPT/L and $2000 \mu \mathrm{g}$ MPT/L exposure concentration the $\mathrm{BM}$ has continuously increased and differ considerably compared to control (F1, $5=10.56, \mathrm{p}=0.011, \mathrm{~F} 1,5=26.28, \mathrm{p}=0.0001, \mathrm{~F} 1$, $5=4.94, \rho=0.05$ respectively). While in $3000 \mu \mathrm{g}$ $\mathrm{MPT} / \mathrm{L}$, tadpole showed a decrease in BM before all of them were dead by $7^{\text {th }}$ day.

In control, we observed that the tadpoles have com- pleted Gosner stage 46 and froglets have emerged. While in $500 \mu \mathrm{g}$ MPT/L tadpoles have grown upto $43^{\text {rd }}$ stage in the same duration. In $1000 \mu \mathrm{g} \mathrm{MPT} / \mathrm{L}, 1500$ $\mu \mathrm{g}$ MPT/L, $2000 \mu \mathrm{g}$ MPT/L and $3000 \mu \mathrm{g}$ MPT/L, tadpoles attained maximum growth of Gosner stage 37, 38,33 and 27 respectively by the time all the tadpoles in control have emerged out as froglets.

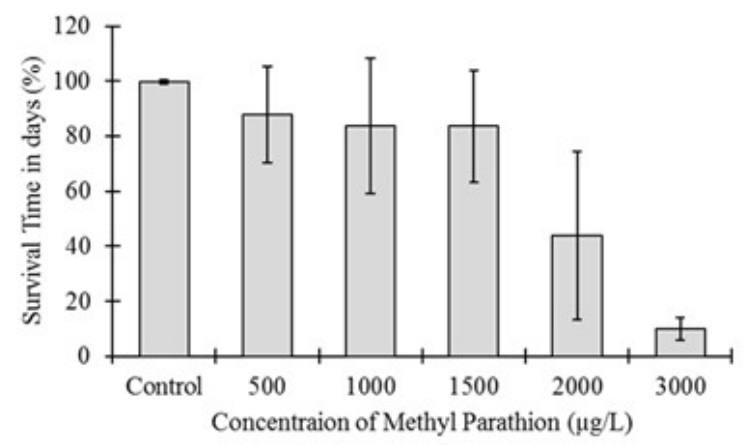

Figure 1. Mean survival time (day $\pm 1 \mathrm{SD}$ ) of tadpoles recorded for 28 days in control and those exposed to different concentrations of MPT
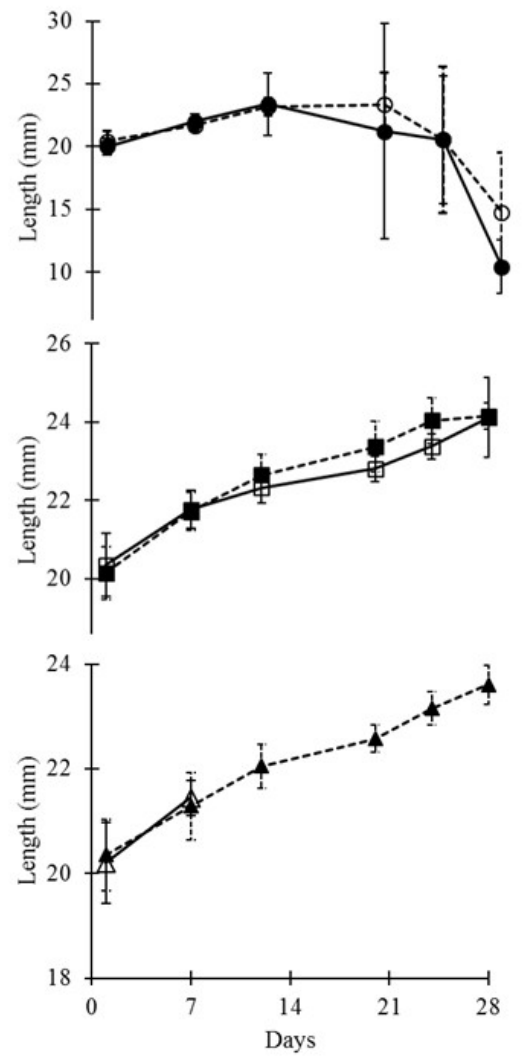

Figure 2. Length $(\mathrm{mm} \pm 1 \mathrm{SD})$ of tadpoles recorded with treatment of different test concentrations of MPT for 28 days (Note: $-1-$ = control; --- $-----=500 \mu \mathrm{g}$ $\mathrm{MPT} / \mathrm{L} ;---\square---=1000 \mu \mathrm{g} \mathrm{MPT} / \mathrm{L} ;-\square-=1500$ $\mu \mathrm{g} \mathrm{MPT} / \mathrm{L} ;---\mathbf{A}---=2000 \mu \mathrm{g} \mathrm{MPT} / \mathrm{L}$ and $-\triangle-$ $=3000 \mu \mathrm{g} \mathrm{MPT} / \mathrm{L}$ ) 


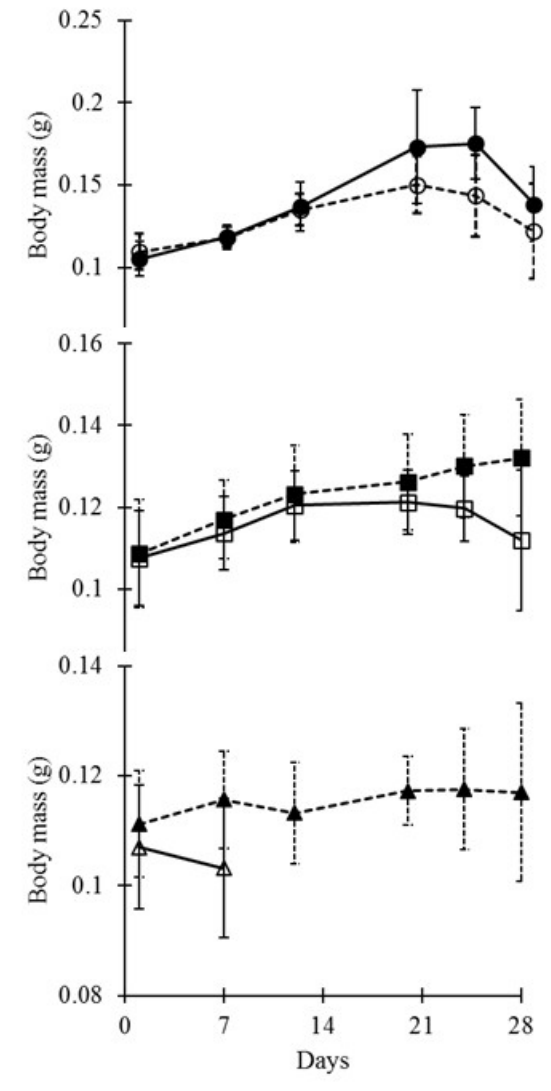

Figure 3. Body mass $(g \pm 1 \mathrm{SD})$ of tadpoles recorded with treatment of different test concentrations of MPT for 28 days (Note: $-1-=$ control; ---O---- $=500 \mu \mathrm{g}$ $\mathrm{MPT} / \mathrm{L} ;-\mathbf{- -} \square---=1000 \mu \mathrm{g} \mathrm{MPT} / \mathrm{L} ;-\square-=1500$ $\mu \mathrm{g} \mathrm{MPT/L} ;---\mathbf{A}---=2000 \mu \mathrm{g} \mathrm{MPT} / \mathrm{L}$ and $-\triangle-$ $=3000 \mu \mathrm{g} \mathrm{MPT} / \mathrm{L}$ )

Methyl Parathion and its active metabolite methyl paraoxon are affecting the development of amphibians $[1,33]$. However, such information of MPT is not available for $F$. limnocharis. In the present study, we observed a drastic reduction in survival over the time. MPT possess a half-life 175 days (at $\mathrm{pH}$ range 1-5, $20^{\circ} \mathrm{C}$ ) and aqueous photolysis half-life range from 8 to 38 days. Since tadpoles of $F$. limnocharis complete their aquatic life around 28-36 days, this pesticide can produce a negative effect on the development of the tadpoles.

The length, body mass and increment in larval stage are considered as the indicator of growth [34-36]. In the present study, continuous monitoring of developmental rate over the time showed that MPT reduced the development of tadpoles. Further, this negative influence is correlated with the concentration of MPT. A similar observation of adverse effects on food consumption, survival of tadpoles and delay in metamorphosis were also observed in the same species by exposing to malathion and combinations with other pesticides [22, 23]. At low concentration exposure $(500 \mu \mathrm{g} \mathrm{MPT} / \mathrm{L}$, $1000 \mu \mathrm{g}$ MPT/L and $1500 \mu \mathrm{g}$ MPT/L), the tadpole mortality was not significantly high. However, low body mass and development (as indicated by Gosner stage) are going to persist, and tadpole will have a long duration of early life. Given such possibilities of MPT contamination in the natural condition and if they are forced to a long larval life, then tadpole may face a severe threat of desiccation of water bodies and other environmental changes occurring over the season.

\section{CONCLUSIONS}

As the larval stages of frog in shallow water and pesticide applications to cropland coincides, tadpoles living in rice paddy croplands have higher chances of being exposed to pesticides. The pesticide Methyl parathion at environmentally realistic concentrations reduced the development and survivability of tadpoles of F. limnocharis. This has been indicated by significant differences in developmental parameters like length and body mass of tadpoles, growth increments and survival rate and time of tadpoles among the tested different concentrations of MPT. At low levels of MPT, although mortality is low, the tadpoles exhibited slow growth. It is believed that if they are forced for a long duration of larval life, then tadpole may face a severe threat of desiccation of water bodies and other environmental changes occurring over the season.

\section{ACKNOWLEDGMENT}

Authors are thankful to Kuvempu University for providing all facilities to conduct this experiment.

\section{REFERENCES}

1. Brühl CA, Pieper S, Weber B (2011) Amphibians at risk? Susceptibility of terrestrial amphibian life stages to pesticides. Environ Toxicol Chem. 30(11): 2465-2472.

2. Fedorenkova A, Vonk JA, Lenders HJR, Creemers RCM, Breure AM, Hendriks AJ (2012) Ranking ecological risks of multiple chemical stressors on amphibians. Environ Toxicol Chem. 31:1416-1421.

3. Weltje L, Simpson P, Gross M, Crane M, Wheeler JR (2013) Comparative acute and chronic sensitivity of fish and amphibians: A critical review of data. Environ Toxicol Chem. 32 (5): 984-994.

4. Nataraj MB, Krishnamurthy SV (2014) Exposure of tadpoles of Fejervarya limnocharis (Anura: Ranidae) to combinations of carbaryl and cypermethrin. Toxicol Environ Chem. 95(8): 1408-1415 
5. Krishnamurthy SV (2003) Amphibian diversity and consequences of habitat dissimulation on their distribution in central Western Ghats of Karnataka. SERC Research Highlight-June 2003. Department of Science \& Technology, Govt. of India, Pp 9-38.

6. Meenakumari (2007) Nitrate tolerance among anuran amphibians of central Western Ghats Ph.D. Thesis: Kuvempu University, India.

7. Adolfo M, Ortiz-Santaliestra M (2009) Pollution: Impact of reactive nitrogen on amphibians (nitrogen pollution). In: Heatwole H, Wilkinson JW eds. Amphibian Biology Vol. 8, Amphibian Decline: Diseases, Parasites, Maladies and Pollution. Surrey Beatty \& Sons, Baulkham Hills, NSW, Australia pp 3112-3144.

8. Mann RM, Hyne RV, Choung CB, Wilson SP (2009) Amphibians and agricultural chemicals: Review of the risks in a complex environment. Environ Pollut. 157:2903-2927.

9. Lehman CM, Williams BK (2010) Effects of current-use pesticides on amphibians. In: Sparling D, Linder G, Bishop CA eds. Ecotoxicology of Amphibians and Reptiles, 2nd ed. Society of Environmental Toxicology and Chemistry, Pensacola, FL, USA, pp 167-202.

10. Hegde G, Krishnamurthy SV (2014) Analysis of health status of the frog Fejervarya limnocharis (Anura: Ranidae) living in rice paddy fields of Western Ghats, using body condition factor and AChE content. Ecotox Environ Contamin. 9(1): 69-76.

11. Berrill M, Coulson D, McGillvray L, Pauli B (1998) Toxicity of endosulfan to aquatic stages of anuran amphibians. Environ Toxicol Chem. 17(9): 1738-1744.

12. Greulich K, Pflugmacher K (2003) Differences in susceptibility of various life stages of amphibians to pesticide exposure. Aquat Toxicol. (Amst) 56:329-336.

13. Rohr JR, Elskus AA, Shepherd BS, Crowley PH, McCarthy TM, Niedzwiecki JH, Sager T, Sih A, Palmer BD (2003) Lethal and sublethal effects of atrazine, carbaryl, endosulfan, and octylphenol on the streamside salamander (Ambystoma barbouri). Environ Toxicol Chem. 22:23852392.

14. Hayes TB, Case P, Chui S, Chung D, Haeffele C, Haston K, Lee M, Mai VP, Marjuoa Y, Parker J, Tsui M (2006) Pesticide mixtures, endocrine disruption, and amphibian declines: Are we underestimating the impact? Environ Health Perspect. 114:40-50.

15. Relyea RA (2010) Multiple stressors and indirect food web effects of contaminants on herpetofauna. In: Sparling D, Linder G, Bishop CA eds. Ecotoxicology of Amphibians and Reptiles, 2nd ed. Society of Environmental Toxicology and Chemistry, Pensacola, FL, USA Pp. 475-486.

16. Ouellet M, Bonin J, Rodrigue J, DesGranges JL, Lair S (1997) Hindlimb deformities (ectromelia, ectrodactyly) in free-living anurans from agricultural habitats. J. of Wildl. Dis. 33:95-104

17. Davidson C, Shaffer HB, Jennings MR (2002) Spatial tests of the pesticide drift, habitat destruction, UV-B, and climate-change hypotheses of California amphibian declines. Conserv Biol. 16:1588-1601.

18. Taylor B, Skelly D, Demarchis LK, Slade MD, Galusha D, Rabinowitz PM (2005) Proximity to pollution sources and risk of amphibian limb malformation. Environ Health Persp. 113:1497-1501.

19. Bishop PJ, Angulo A, Lewis JP, Moore RD, Rabb GB, Moreno JG (2012) The amphibian extinction crisis: what will it take to put the action into the Amphibian Conservation Action Plan? Sapiens (Online) 5.2.

20. Gardner T (2001) Declining amphibian populations: a global phenomenon in conservation biology. Anim Biodiv Conser. 24: 25-44.

21. Vasudev V, Krishnamurthy SV, Gurushankara HP (2008) Organophosphate pesticides - a major threat to anuran populations in an agroecosystem of Western Ghats, India. Froglog 83: 8-9

22. Gurushankara HP, Krishnamurthy SV, Vasudev V (2007a) Effect of malathion on survival, growth and food consumption of Indian cricket frog (Limnonectus limnocharis) tadpoles. Arch. of Environ. Contam. Toxicol. 52: 251-256.

23. Nataraj MB, Krishnamurthy SV (2012) Effects of combinations of malathion and cypermethrin on survivability and time of metamorphosis of tadpoles of Indian cricket frog (Fejervarya limnocharis). J. of Environ. Sci. Health Part B47(2): 67-73.

24. Gurushankara HP, Krishnamurthy SV, Vasudev V (2007b) Morphological abnormalities in natural populations of common frogs inhabiting agroecosystems of central Western Ghats. Appl Herp. 4: 39-45.

25. Patel AM, Kulkarni PA, Girish KG, Gurushankara HP, Krishnamurthy SV (2008) Cricket frogs: morphological abnormalities Herp Review. 31(9): 77.

26. Daniels RJR (2005) Amphibians of Peninsular India, Universities Press, India

27. Watson FL, Schmidt H, Turman ZK, Hole N, Garcia H, Gregg J, Tilghman J, Fradinger EA (2014) Organophosphate pesticides induce morphological abnormalities and decrease locomotor activity and heart rate in Danio rerio and Xenopus laevis. Environ Toxicol Chem. 33: 13371345.

28. Anguiano OL, Montagna CM, Chifflet de Llamas M, Gauna L, Pechen de D'Angelo AM (1994) Comparative toxicity of parathion in early embryos and larvae of the toad Bufo arenarum Hensel. Bull Environ Contam Toxicol. 52: 649-655. 
29. Chaiyarat A, Tangpraprutgul P, Pariyanonth $\mathrm{P}$, Wattttanasirmkit K (2003) Effects of methylparathion on the re productive system in Male Frogs, Hoplobaprachus rugulosus. J. of Sci. Res. Chula. Univ. 28: I (NRC-EHWM) 3040.

30. Gosner KL (1960) A simplified table for staging anuran embryo and larvae with notes on identification. Herpetologica 16:183-190.

31. Sabnis JH, Kuthe SN (1978) Observation on food and growth of Bufo melanostictus tadpole. J. of Bombay Nat. Hist. Soc. 77: 21-25.

32. Gurushankara HP (2007) Cytogenetical and biochemical effects of organophosphate pesticides malathion and parathion on Rana (Limnonectus) limnocharis. Thesis: Kuvempu University, Shivamogga, India.
33. Calumpang SM, Medina MJ, Tejada AW, Medina JR (1997) Toxicity of chlorpyrifos, fenobucarb, monocrotophos, and methyl parathion to fish and frogs after a simulated overflow of paddy water. Bull Environ Contam Toxicol. 58: 909-914.

34. McDiarmid RW, Altig R (Editors) (1999) Tadpoles: the biology of anuran larvae. The University of Chicago Press Pp.208.

35. Miaud C, Üzüm N, Azaz A, Olgun K (2007) Age, size and growth of the endemic Anatolian mountain frog Rana holtzi from Turkey. Herpetol J. 17: 167-173.

36. Burton EC, Gray MJ, Schmutzer AC, Miller DL (2009) Differential responses of post metamorphic amphibians to cattle grazing in wetlands. J. of Wildl. Manag. 73: 269-277. 